\title{
Bio-economy as a Concept of Development Strategies in the European Union
}

\author{
Mieczysław Adamowicz \\ Professor, Faculty of Economic Sciences and Technology, Pope John Paul II State School of Higher Education in Biała Podlaska, Poland
}

\begin{abstract}
2017 Research Leap/Inovatus Services Ltd. All rights reserved.

DOI: 10.18775/jibrm.1849-8558.2015.24.3001 URL: http://dx.doi.org/10.18775/jibrm.1849$\underline{8558.2015 .24 .3001}$

\section{Keywords:}

Bio-economy, Biotechnology, Development strategies, Economy based on biomass.

The aim of the study is to present the concept of bio-economy and its development factors, as well as the analysis and evaluation of the use of the bio-economy concept in shaping development strategies in the European Union. Particular attention is paid to bio-economy as part of a sustainable development strategy, implementation of innovations and formation of smart specialization of regions. On the basis of available literature and documents of the European Union, as well as other institutions, bio-economy is presented as a new economic category, and bio-economy development factors and bio-economy itself are presented as a strategic planning tool. One of the key conclusions is the statement that bio-economy, which constitutes an important sector increasing in significance within the real economy, is a new interesting analytical and cognitive concept in economics and also a useful tool in strategic planning development.
\end{abstract}

\section{Introduction}

The notion of bio-economy emerged in a literature of the late 20th century (Martinez 1998). However, it was not until the second decade of the 21st century that it has attracted a great interest of scientists and circles shaping development strategies. As a new theoretical and analytical concept, at the same time constituting a planning category, bio-economy has gained high popularity while various development strategies were being shaped in the European Union. Separation of various segments of the real economy relating to utilization of living organisms of plants, animals and microorganisms and their integration into one large segment (complex) of real economy, which is the essence of bio-economy, has become a useful tool for the development of various plans and development strategies throughout the European Union, in the Member States and individual regions. Non-European countries, mainly the United States, as well as international organizations, OECD in particular, have also displayed interest in bio-economy.

The aim of this article is to present the concept of bio-economy and factors of its development and the analysis and evaluation of the use of the bio-economy concept in shaping development strategies of the European Union. Particular attention will be paid to bio-economy as part of the sustainable development strategy, implementation of innovations, the formation of value chains and specialization of regional development. This work is based on source literature of policy papers and reports of various institutions, as well as community and international organizations.

\section{Bio-economy as a New Economic Category}

First attempts to define bio-economy took place in the years 1997-1998 in the research community cooperating with the European Union institutions. Juan Enriques and Radrigo Martinez recommended an authorial definition that sparked the interest of the European Union in bioeconomy as an analytical and cognitive category, useful for programming development strategies for the future. The aforementioned authors perceived bio-economy as an economic activity based on scientific research and implementation focused on understanding the mechanisms and processes at the molecular (genetic) level, with the aim to implement and use it in industrial processes (Martiez 1998).

The first stage of the concept development was associated with the dynamic development and achievements in the fields of biology and biotechnology (EC 1993, EC 2000). Attention was then directed towards linking bio-economy with the environment, ecological development, and sustainability. Keen interest in bio-economy in the first decade of the $21 \mathrm{st}$ century resulted in the formulation of many definitions of the term. The way bio-economy is defined is important due to the fact that methods and components of its definition are directly reflected in the policies, programs, and strategies of economic development (Maciejczak, Hofreiter 2013). Different definitions emphasize various technological, economic and social aspects and priorities, and relate to various conditions and developmental concepts such as sustainable development and innovative development, both at national and regional levels.

Bio-economy can be perceived differently not only in individual countries but also by entities in different sectors of the economy. However, it has a 
cross-sectorial character. A common feature, independent of the sector, is considering this concept from the point of view of innovation and economic benefits, which may not only result from its development but also the inherent risk that accompanies it. Despite the differences, it is widely recommended to support the development of bio-economy through state policies and institutions designated for that purpose.

Generally, bio-economy can be defined as an economy, in which the main production components - manufacturing of materials, chemical products, and energy, are based on biological and renewable resources (McCormick, Kautto 2013). Bio-economy in its production processes utilizes biomass obtained from reproducible biological resources of plant or animal origin, which are processed in the mechanical, biochemical and thermo-chemical way (Fig.1). In addition to trees, shrubs, crops, and plantations, the following are also used: algae and aquatic plants, waste and primary agricultural residues, waste and secondary agricultural residues, and successive generations of waste and residues. The use of biomass in economic processes allows obtaining thermal energy, liquid fuels, chemicals, bioproducts, food and fodder as well as cosmetics and medicines.

Biomass Production Processing of Biomass Utilization of Biomass
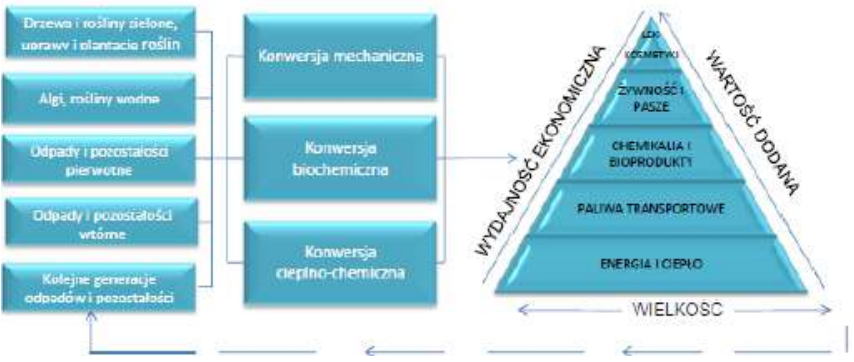

Figure 1. The concept of economy based on biomass

Source: Own calculations based on Bas Eichaut Saerates Schauten. Concept van den Biobased Economy, http://biobasedeconomy.nl

The definition formulated in 2005 by the Directorate-General for Research and Innovation of the European Commission states that "bioeconomy constitutes an environmentally friendly, ecologically efficient conversion of renewable biological resources for food, energy and other industrial products". Similarly, in 2006 the Research DG has developed the concept of bio-economy by specifying that it includes "all production systems that use biochemical and biophysical processes, including all natural science and related technologies that are applied, and necessary to produce useful products, including biotechnology applied in agriculture and industry. Bio-economy also encompasses biorefineries, production of bioenergy and biochemicals, innovative means of using the land and the sea to create public goods as well as the use of materials generally regarded as waste (EC 2012).

Countries with well-developed agriculture and biotechnology, as well as large natural biological resources have also directed their attention to the development of knowledge-based bio-economy. A view that "bioeconomy covers the production of renewable biological resources and their conversion into food, fodder, medicines and other bioproducts and bioenergy," which became widespread in the EU member states, was presented during a conference held at the time of the German Presidency in the EU in 2007. This visionary document stressed that biotechnology will be a key component of the European economy by 2030 (Cologne Peper 2007). This document pays particular attention to an increase in participation and importance of the so-called white biotechnology products (medicaments, cosmetics, etc.) and of bioenergy in industrial production in Europe (McCormick, Kautto 2013).

OECD has defined the concept of bio-economy in 2006 and has determined its use in the development policy. This organization recommends that "bio-economy is the aggregated set of economic operations in a society, which uses the latent (hidden) values embedded in products and in biological processes in order to accelerate the increase and achieve prosperity for citizens and nations" (OECD 2006). In 2009 the OECD reports that "bio-economy means the exchange of knowledge resulting from the natural sciences to the new, environmentally friendly eco-efficient and competitive products." A depiction of 2009 focuses on the fact that bio-economy should be perceived as a reality, in which biotechnology is an important factor influencing economic growth (McCormick, Kautto 2013). Developing this concept of OECD shows that bio-economy includes three elements (The OECD 2009):

- using of advanced knowledge on genes and cellular processes for programming and for the development of new processes and products;

- using of renewable biomass and effective bioprocesses in order to stimulate sustainable production;

- integration of knowledge of biotechnology in order to apply it in a wide range of sectors.

OECD justified that biotechnologies can solve many global problems related to health and nutrition, and suggested that biotechnology and bioeconomy will enable significant changes in the global economy in the course of three decades. During forming this concept, OECD used the achievements of various European and American institutions, including the definition of the British minister of the Department of Environment, Food and Rural Affairs (DEFRA). In 2007 DEFRA defined bio-economy as "economic activity, which grabs value hidden in biological processes and renewable bio-resources, which results in better health, growth and environmentally friendly development " (DEFRA 2007).

While in 2007 the concept of bio-economy was relatively new and unknown (Hilgartner 2007), the rapid spread of the concept took place in the years 2010-2013, which was also influenced by activities of various organs of the European Union. According to the concept formed in the draft platform for gathering information for the bio-economy (BECOTEPS 2010), "bio-economy means all sectors whose products are biomass-derived" and "this part of the economy, which through the development generates growth and creates workplaces in the process of using and processing of biological resources in an environmentally friendly way "(Maciejczak, Haffreiter 2012).

The European Commission in the document from 2010 entitled "Bioeconomy for Europe" presented the production models based on biological processes and natural ecosystems using natural materials, which consume minimal amounts of energy without generating waste, as all waste resulting from one process is the material for the next and as a result it is reused in the ecosystem (EC 2010). Similarly, bio-economy was defined in the documents of the European Union published in 2011 (ETP 2011, Europe Bio 2011), where bio-economy was referred to as "sustainable production and processing of renewable mass into a wide range of products and food, medical, industrial and energy services or for various biological materials for direct using and in the form of raw materials for the manufacture of other products "(Menard and others 2011, Schmidt and others 2012).

Defining bio-economy in the United States has many similarities as compared to the definition developed by the OECD and in the European 
Union. Definition from 2012 published in the documents of the White House states that "bio-economy is an economy based on the use of research and innovation in biological sciences in order to power the economic activity and to generate public profits (The White House 2012). In this country, more attention is being paid to industrial biotechnology, biofuels, biorefineries, chemical industry, transport, and recycling. These areas are mainly within the scope of the so-called gray bio-economy.

The most comprehensive and extensive definition is the one formed in 2012 by the European Commission due to developing the strategy of using renewable biological resources in various sectors of the economy (EC 2012). According to this definition "bio-economy is the sustainable production of renewable biological resources and their processing into food products, feed and industrial goods and into bioenergy, which is based on agronomy, ecology, food sciences, social sciences, biotechnology, nanotechnology, ICT and engineering and includes agriculture, forestry sectors, fishing industry, food, pulp and paper production as well as elements of the chemical, biotechnology, energy and transport sector" (EC 2012, Chyłek 2012).

The definition of bio-economy given by the European Commission is not final. Conditions are constantly changing, new products and solutions are appearing, and concepts of development are modified. In the years 20152016 a number of new reports were published resulting from research and deliberations of various conferences i.e. of conference of Standing Committee on Agricultural Research (SCAR).

In the SCAR's report presented at the conference "Sustainable agriculture, forestry and fishing industry in bio-economy - challenges for Europe" in October 2015 in Brussels there appeared new elements related to bioeconomy, which were confirmed by the IV Cyclical Conference in April 2016 in Utrecht, where a document in the form of a manifesto entitled "European Bio-economy Stakeholders Manifesto" was prepared. In this document attention was paid to the need for efficient management of raw materials and recycling in a closed circuit - from production through use in order to dispose and process of waste, i.e. the so-called "from cradle to grave" concept; forming a hierarchy and applying the principle of cascading in the biomass chain; creating and strengthening the concept of "product life cycle" and "value chains" within the scope of bio-economy. All these depictions draw attention to the need to strengthen the meaning of the term "sustainability" in the development strategies, i.e. the offsetting and durability, as well as the importance of innovation and participation in actions implementing strategies.

\section{Development Factors of Bio-economy}

Bio-economy is a concept embedded in practical activity and in attempts to describe it scientifically. As a consequence, this description leads to its further use in the activity being aimed at improving the practical activity. Taking this into account, bio-economy can be regarded as (Adamowicz 2014):

- a separate sector of the modern economy;

- a new analytical and cognitive concept of scientific nature;

- a cross-sector, strategic form of analysis and programming of practical and scientific activities.

The first look shows that bio-economy is a large and rapidly growing sector of the modern economy, which uses biological resources in the economic processes - living organisms, biotechnologies, bioproducts and bioprocesses to produce new products and services. The bioproducts used are manufactured in different branches of the economy - agriculture, forestry, fisheries, aquaculture, etc. Using new products goes far beyond the realm of food production, especially in the sphere of production of medicines, industrial products, and energy.

The second view concerning the concept of bio-economy means that it is treated not as a new theoretical concept but rather as a new concept concerning an analytical and cognitive view on the economy, which grew out of the needs of science and practice, and helps scientists conduct research and makes it possible for recipients to understand the nature and relations between the various components. This is not an entirely new, although revised, expanded and adapted to modern needs view of reality compared to for example the concept of agribusiness and food economy. A new challenge for this concept is to integrate it with the concept of sustainable development.

A third aspect says that bio-economy is a strategic form of intelligent actions enrolling in interdisciplinary planning and funding of research and use of human capital. A bio-based economy may also be perceived as a creative development and new uses of previously known development concepts relating to agribusiness, agriculture and rural areas with extension to other sectors: forestry, fisheries, manufacturing, and energy use of waste.

In reference to various approaches to the concept of bio-economy, several groups of premises for the formation and development of bio-economy can be differentiated. Each new concept is an outcome of the past; it has its roots in practical activities and activities attempting to describe it in a scientific manner. By trying to describe bio-economy in a scientific manner, one should pay attention to the three most important groups of its creation: general premises, conditions in the field of science and technology, conditions referring to the previously separated theoretical approaches (Chyłek, Rzepecka 2011 EC 2012 Golebiewski 2013 McCarmick Kautto 2013).

The group of general conditions includes population growth, improved incomes and general welfare, diversification of consumer preferences, production capacity, usage of new technologies, searching for rational management of resources and new sources of energy, internationalization, and globalization of the economy, the development of international integration, etc.

Despite different trends in the regional system, there is a further increase in world population. In many countries, there was an improvement of incomes and general wealth of the population. This applies especially to a large group of developing countries that have undergone or are undergoing a socio-economic transformation. This results in an overall increase in the demand and the diversity of consumer preferences. To ensure food security and to meet greater and more diverse demand it is not enough to implement conventional methods and techniques of production. The degree of processing of biological resources is expanding, new branches of processing are developing, and new products emerge. Development of various forms of progress and new technologies increase production capacity, market supply, and variety within production offer. This allows reducing the barriers to the growth of agricultural production and other forms of production, associated with the use of biological materials resulting from the slower growth of food consumption with the increase in population income.

At the same time more widely recognized is the need for rational management of available resources, especially non-renewable ones. The need for multiple uses of raw materials through the creation of organized forms of recycling and modern waste management increases. The most important aspect is refraining from relying on non-renewable energy 
sources and transition to the wider use of renewable energy. The presented phenomena are becoming increasingly common in every country and every place due to processes of internationalization and globalization of economy and support created by the process of international integration, thanks to the signing of global agreements concerning international trade, environmental protection, and climate change. Problems shown become the subject of conscious development of strategies of sustainable development in individual countries as well as internationally. The most mature forms of these activities on an international scale in a variety of strategies and development policies have been developed in the European Union and individual member states of this organization.

The development of bio-based economy facilitates rapid development of science technology and technology, particularly in the field of biological sciences and computer science. Initially, researches and scientific achievements had a great influence on genetics and molecular biology, as well as biotechnology industries. Currently, modern technologies providing the possibility to manufacture new products from biomass are getting increasingly popular. Using a range of colors you can talk about green, red and blue biotechnologies, referring to the colors of a green mass of crops and forest plants, animal products or products resulting from fishing in inland and sea waters. There is also mention about pure industrial biotechnologies, white in the pharmaceutical industry and health care, and gray in the manufacture of special chemicals or energy. Black technologies used in the processing of waste and wastewater treatment, as well as recycling, are currently of greater significance.

Modern biotechnologies increase the opportunities for manufacturing new materials and products, for which raw material is the biomaterial used in various sectors of the economy. The whole process of development and use of biotechnology enables and facilitates the development of microelectronics and utility systems, data processing and communication between the participants of economic processes and research and development. Especially effective communication processes occur in developing network systems in the economy and society.

The basic premise for the concept of bio-economy is the need to seek out how to move from a traditional economy based on fossil fuels to an economy based on renewable biological energy sources to bio-economy and bio-society, the development of which will be driven by research and innovation on biological renewable energy sources. The term "bioeconomy" means the economical use of biological resources of sea and land, as well as waste and re-using them in the production processes (Adamowicz 2014).

The phenomena described above have been noticed by government bodies managing the process of integration in the European Union and used in programming and implementation of development plans of the European Communities. A new concept of bio-economy and KBBE was introduced to the practice of programming, forecasting and modeling the development of the strategic dimension, both at EU level and in the Member States.

Prerequisites for the development of bio-economy grown on the grounds of theory and analysis of scientific evidence and implementation are important in terms of science. Scientific roots of the bio-economy concept can be linked to three theoretical notions and associated practical activities: theory and practice of agribusiness and food economy, the theory and practice of sustainable development, which is still widespread and valid, mentioned in numerous papers and scientific publications, and the theory of regional development, which gives rise to the choice of specialization of the region, especially important for the development of the outermost regions.

The theory of agribusiness and food economy, as well as the theory of sustainable development, are well known to agricultural economists and therefore do not require a broader interpretation. The issue of the development of the outermost regions is also a common subject of interest to experts involved in the development of agriculture and rural areas. The theory of regional development, giving rise to the choice of region specialization is particularly essential for the development of outermost regions.

The roots of the bio-economy concept are also found in conscious activities of European Union authorities, particularly in analyses, reports, plans, and strategies developed by them, which aim at the developmental convergence of Member States.

\section{Bio-economy as a Tool for Planning Development Strategies}

The basis for the development of the European bio-economy concept may be found in documents of the European Union gathered in the years 1993 2007. The first one was the so-called White Paper published in 1993 , reflecting the need to develop non-tangible, knowledge-based investments, which also included biotechnologies. The Lisbon Agenda adopted in 2000 outlines a strategy for the development of knowledgebased economy (EC 2000), competitive to the US. In 2002, the European Commission stated that natural sciences and biotechnology are probably the most future-oriented technologies to achieve the objectives of the Lisbon Agenda. In 2005, the European Commission outlined the "New Perspectives on Bio-economy," and in 2007 the European Council outlined the perspective of the development of bio-economy for the next twenty years (German Presidency 2007). These events helped establish the concept of Bio-economy based on knowledge used in the circles shaping European development policy (McCormic, Kautto 2013).

Since the beginning of the second decade of the twenty-first century, in the years 2010-2012, the European Union has taken steps to establish a new development strategy dating back to years 2020-2030 (Adamowicz 2014). The basic document defining the future of Europe was a "Strategy for smart, sustainable and inclusive growth-Europe 2020", which was related to a plan to provide sustainable bio-economy (EC 2010). The document entitled "Innovation for Sustainable Growth: Bio-economy for Europe" presented the concept of sustainable use of renewable biological sources in different areas of the economy, especially those like: agriculture, forestry, fisheries, manufacturing, waste food, energy, materials management and other branches of industry (EC 2010). The plan also involves the EU Framework Horizon Programme for Research and Innovation 2020 (EC 2012), which takes into account the need to increase public funding for scientific research and innovation on bioeconomy. It concludes that bio-economy has become an important area of interest of EU bodies and is associated with the implementation of various community policies and national policies of the Member States. The concept of bio-economy is being constantly supplemented and enriched with new elements.

In formulating the concept of bio-economy, the European Union included it in the sphere of strategic actions meeting the challenges of today. Implementation of one of the main strategic objectives, which is the transition of the economy's dependence on fossil fuels to make a full use of renewable energy sources and materials by integrating the activities of science, the economy, the state and civil society, can be done by (ETP 2010): 
- Acceleration of basic knowledge combination and the development of new technologies and uptake of innovation. This can be achieved through increased research, better education, and implementation activities. Creating systems, network layouts, and business development can play a key role.

- Development and implementation of new, adequate economic structures, an efficient risk management system and implementation of international cooperation.

- Building a solid foundation for the continuity of progress by developing research programs, encouraging innovation, improving the functioning of markets and targeting educational programs.

- Obtaining broad acceptance and social support for the implementation of the concept of bio-economy and its continuous improvement.

The new European bio-economy concept developed in the years 20112012 sought to overcome many of today's challenges and introduced appropriate strategic actions.

Transformation of the theoretical concept of bio-economy into an efficient system of practical actions requires integrated actions of politicians, businessmen, scientists, activists, local government, investors and other stakeholders and ordinary citizens. To accomplish this, functioning information systems, targeted educational activities, adequate systems of support and promotion, the availability of financial resources and favorable climate and social dialogue are needed. It is also necessary to implement an adequate system of organization and management in chains and networks of bio-economy, as well as monitoring and evaluation. An important step was the creation of a special system of the bio economic and biotechnological platform for knowledge called BECOTEPS. In the sphere of science, the European program for research and innovation "Horizon 2020", the European Institute of Innovation and Technology were launched. Organizational support for strategic activities is also created by the Standing Committee for Agricultural Research SCAR, Foresight conferences, through which the EU concepts of practical actions are transmitted to individual countries.

The European strategy and action plan for bio-economy up to the year 2020 assume the implementation of various objectives that can be specified as follows (EC 2010):

- strengthening European leadership and creativity in the field of biological sciences;

- optimizing the system of innovation and knowledge transfer;

- testing to ensure a safe, accessible and well-balanced food;

- implementing sustainable systems of rural economy and water;

- improving production and distribution of agricultural products and food;

- maintaining the competitiveness of European agriculture and food processing;

- developing low-carbon industries;

- reducing greenhouse gas emissions and waste.

Objectives specified above in conjunction with other strategic programs on innovation, natural resources, finance, research and sectoral policies (agriculture, fisheries) outlined until the year 2020 are a key element of the smart, sustainable program, inclusive of all growth in Europe (EC 2012). It was assumed that defining the concept of bio-economy will create new opportunities and impulses for economic growth, increase employment, enhance the environmental, economic and social sustainability of rural, coastal and industrial development.
The European strategy for the development of bio-economy in documents from 2012 was based on three pillars (EC 2012):

- Investment in research, innovation, and skills in the field of bioeconomy financed from EU funds, both national and private, and the search for synergies with other initiatives and politicians;

- Strengthening the interaction and political coordination, as well as greater involvement of stakeholders through the establishment of the panel and the Bio-economy Observatory, and regular organization of conferences and consultations of stakeholders.

- Development of markets and competitiveness in bio-economy sectors by the sustainability of primary production and conversion of waste streams into value-added products, as well as through mechanisms of mutual learning in order to improve production and management.

By introducing the concept of bio-economy and its development, the European Union tried to reinforce the belief that Europe is the world leader in various areas of bio-economy and related technologies. This applies especially to biotechnology in the chemical industry, the food industry, and the feed industry. However, in this regard, you can observe strong competition from other highly developed countries. It was attempted to reshape areas of different development policies and to strengthen the relations between them while implementing the concept of bio-economy. New support institutions such as the European Platform Panel and the Bio-economy Observatory are supposed to serve it. The development strategy is also made into a practical action plan. A plan for the bio-economy strategy includes main activities leading to the achievement of strategic objectives using existing programs and policies, including the common agricultural policy, regional policy, industrial, environmental, climate, energy and other policies.

\section{Prospects for the Use of the Concept of Bio-economy}

One of the biggest challenges of the present, both in economic and political terms, facing the European countries and other countries in the world is to focus the economy on sustainable development through the use of human-friendly and eco-friendly, innovative and efficient techniques and technologies in the use of natural resources. Using the achievements of science and technology for development purposes within the framework of sustainable production systems should include an important element of such a system like bio-economy. Some documents of EU institutions on the European Strategy Development and currently ongoing discussions and activities on the preparation of a variety of formal legal and organizational solutions that can be used by member countries have drawn attention to the validity of such concepts. One example of such actions is conferences of the Standing Committee on Agricultural Research (SCAR), where new research results on bioeconomy are presented. According to the preliminary report of the Foresight group of experts presented in the spring of 2015 on SCAR conference, bio-economy has the potential to solve problems such as food security, sustainable management of resources, reducing dependence on non-renewable resources, reducing adverse climate change, creating jobs and remaining competitive.

In 2016 the European Commission has announced a revision of the Communication of 2012 called "Innovation for Sustainable Growth; Bioeconomy for Europe (COM 2020/60), which explained the concept of European bio-economy. The new bio-economy packet in closed circulation assumes the following:

- developing environmental standards for secondary raw materials in order to facilitate their identification and increase the potential for their use in the single market; 
- implementing the strategy on plastics in the economy by a closed circulation relating to the issue of recycling, biodegradability and the presence of hazardous substances in plastics and the goals of sustainable development in terms of reducing the amount of waste in the sea;

- measures to reduce food waste;

- changes concerning the characteristics of organic fertilizers and used from waste, and supporting the role of biological ingredients in fertilizers;

- promoting the re-use of waste water.

Implementation of the foregoing solutions is aimed to achieve a higher rate of recycling of municipal waste and packaging waste by 2030. This will also reduce waste stream destined for disposal by 2030. A total ban on storage of sorted waste is also assumed. Building the economy in a closed circulation will have a significant influence on reducing the negative impact of the life cycle of products on the environment. This strategy will create real challenges for households and small and mediumsized enterprises.

\section{Conclusion}

The development of the concept of bio-economy and its use in building development strategies and the implementation of economic development policies and sectoral policies both in the EU and the individual member states and regions is essential for further activities in the following areas:

1. Functioning and development of agriculture, agribusiness, and rural areas. Agriculture and food industries in Poland are key areas of economic impact and social development within bio-economy. Bioeconomy strengthens the role of other industrial and energy sectors, which are included in development strategies.

2. Bio-economy is a category that is significant for the formation of specialization in regional development. Particular countries and regions have established the so-called smart development specializations among which bio-economy is marked, as a whole or its particular elements.

3. The concept of bio-economy had a significant influence on the choice of leading directions and on the scale of supporting the research, implementation and innovation activities. At the EU level, it was reflected in the Horizon 2020 research. In Poland, a research program called Biostrateg has been launched.

4. An important effect of the development of bio-economy is its contribution to the creation of economic value and strengthening the competitiveness of entire countries, sectors, and branches that form a complex bio-economy. The competitive relationship between the partners' changes in the chains forming products of bioeconomy.

5. Bio-economy can have an important function of integrating various economic sectors. It can also be an important factor in strengthening international integration. What is needed is research on bioeconomy and conscious support of its development. It will strengthen its role as a tool to prepare the strategy and implement development policies.

\section{References}

\section{Journal Papers}

- Adamowicz, M., (2014), European concept of bioeconomy and its bearing on practical use, Economic and Regional Studies Volume 7 No 4.

- Chyłek, E., (2012) Biogospodarka w sektorze rolno-spożywczym. Przemysł spożywczy 5 pp. $34-35$.
- Chyłek, E. K., Rzepecka, M., (2011), Biogospodarka konkurencyjność i zrównoważone wykorzystanie zasobów, Polish Polish Journal of Agronomy 7, pp. 3-13.

- Gołębiewski, J., (2013), Zrównoważona biogospodarka - potencjał i czynniki rozwoju, IX Kongres Ekonomistów Polskich.

- Hilgartner, S., (2007), Making the Bioeconomy Measurable: Politics of an Emerging Anticipatory Machinery, BioSocieties, pp.382-386. $\underline{\text { Crossref }}$

- Maciejczak, M., Hofreiter, K., (2013) How to define Bioeconomy, Roczniki Naukowe Seria, volume XXV, book 4.

- Martinez, J., (1998) Genomies and the World's Economy, Science Magazine, vol. 281no 5379 pp. 925-926.

- McCormick, K., Kautto, N., (2013) The Bioeconomy in Europe: An Overview, Sustainability No 5.

- Menard, K., Eberle, H., Schmidt, O., Vanhemelrijck, J., Viaggi, D., (2011) Assessment of the impacts of the European Bio-Based Economy, Expert Raport for AG Ressearch EU Commission, Brussels.

- Schmidt, O., Padel, S., Levidow, L., (2012) The Bio-Economy Concept and Knowledge Base in a Public Goods and Farmer Perspective, Biobased and Applied Economics (1) pp. 47-63.

\section{- European Union Documents and Internet Sources}

- Becoteps (2010), Bio-Economy Technology Platforms.

- Defra (2007), UK Biomass Startegy, White Policy Paper, London.

- EC (1993), EC; Growth, Competitiveness, Employment: The Challenges and Ways Forward into the 21st Century. White Paper, Com (93) 700 Belgium.

- EC (2000), The Lisbon European Council: An agenda of economic and social renewal for Europe: Brussels.

- EC (2010), Bioeconomy Europe 2020. A Strategy for Smart, Sustainable and Inclusive Growth, Brussels http://european/eu/2020.

- EC (2012), Innovating for Sustainable Growth: A Bioeconomy for Europe, Brussels.

- En Route to the Knowledge-Based Bio-Economy. 2007 Cologne Paper: http://www.bio-economy.net/reports.

- Etp (2011) The European Bioeconomy In 2030 Delivering Sustainable Growth by ad dressing the Grand Societal Challenges.

- Europa Bio (2011) The Bioeconomy for Europe: Innovating and Sustainability

- European Bioeconomy Stakeholders Manifesto, (2016) Dokument będący wynikiem konferencji w dniach 12 - 13 kwietnia 2016 r. w Utrechcie, dotyczący biogospodarki.

- German Presidency (2007), En Route to the Knowledge-Based BioEconomy, German Presidency of the Council of the EU: Cologne, Germany.

- OECD (2006) The Bioeconomy to 2030: Designing a Policy Agenda, Scoping Document, Paris.

- OECD (2009) The Bioeconomy to 2030: Designing a Policy Agenda, Main Findings, Paris.

- The White House (2012), National Bioeconomy Blueprint, Washington DC.

\section{- Note}

- Early shorter version of this paper was presented at the 2017 International Conference "Rural Environment, Education, Personality 2017 organized by Llu Esaf in Jelgava, Latvia, 12-13.05.2017. 